\title{
First description of the female Zelotes occultus Tuneva et Esyunin, 2003 (Aranei: Gnaphosidae) with data on the distribution of the species
}

\section{Первоописание самки Zelotes occultus Tuneva et Esyunin, 2003 (Aranei: Gnaphosidae) с данными о распространении вида}

\author{
Tatyana K. Tuneva ${ }^{1}$, Aleksandr V. Ponomarev ${ }^{2}$ \\ Т.К. Тунёва ${ }^{1}$, А.В. Пономарёв ${ }^{2}$
}

\footnotetext{
${ }^{1}$ Institute of Plant and Animal Ecology Ural Branch of Russian Academy of Sciences, 8th March Str., 202, Ekaterinburg 620144 Russia. E-mail: tuneva@ipae.uran.ru

${ }^{2}$ Southern Scientific Centre of Russian Academy of Sciences, Chekhov Str., 41, Rostov-on-Don 344006 Russia.

E-mail: ponomarev1952@mail.ru

${ }^{1}$ Институт экологии растений и животных УрО РАН, ул. 8 Марта, 202, Екатеринбург 620144, Россия.

2 Южный научный центр РАН, пр. Чехова, 41, Ростов-на-Дону, 344006 Россия.
}

KEY WORDS: Araneae, spider, steppe zone, Russia.

КЛЮЧЕВЫЕ СЛОВА: Araneae, паук, степная зона, Россия.

ABSTRACT. The female of Zelotes occultus Tuneva et Esyunin, 2003 is described for the first time on the basis of newly collected material from the Volgograd and Rostov Areas of Russia. The species seems confined to the steppe zone south-east of the Russian Plain and inhabits plains of large rivers.

How to cite this article: Tuneva T.K., Ponomarev A.V. 2019. First description of the female Zelotes occultus Tuneva et Esyunin, 2003 (Aranei: Gnaphosidae) with data on the distribution of the species // Arthropoda Selecta. Vol.28. No.3. P.445-447. doi: 10.15298/ arthsel. 28.3.09

РЕЗЮМЕ. На основе материала из Волгоградской и Ростовской областей России приводится первоописание самки Zelotes occultus Tuneva, Esyunin, 2003. По-видимому, распространение данного вида ограничено степной зоной юго-востока Русской равнины с локальной приуроченностью к долинам крупных рек.

\section{Introduction}

Zelotes occultus Tuneva et Esyunin, 2003 was described from the Orenburg Area (Aytuar) on the basis of three males [Tuneva, Esyunin, 2003]. Later Ponomarev \& Khnykin [2013] reported a male and seven females from the Volgograd Area, but the females were not described. The goal of this article is to describe the female of $Z$. occultus and summarize the distribution data of this species.
Material and methods

Material presented herein will be deposited in the Department of Invertebrate Zoology and Aquatic Ecology of the Perm State University (PSU, curator: S.L. Esyunin) and in the personal collection of A.V. Ponomarev (CP) (Rostov-on-Don, Russia).

Photographs were taken at the Southern Scientific Center of the Russian Academy of Sciences with a MICMED-6 microscope using a SONY NEX-C3 $16.2 \mathrm{mp}$ digital camera and Microphotoset (MFN-12). Electron-optical images were taken in an interdisciplinary analytical laboratory of the Southern Scientific Center of the Russian Academy of Sciences using an EVO-40 XVP scanning electron microscope (LEO $1430 \mathrm{VP})$ at an accelerating voltage of $15-18 \mathrm{kV}$.

Terms and abbreviations for the copulatory organs are adopted from Miller [1967] and Senglet [2004]. The following abbreviations are used in the text: $d$ - dorsal; $p$ prolateral; $\mathrm{r}$ - retrolateral; $\mathrm{v}$ - ventral. Lengths of leg segments were measured on the dorsal side. All measurements are given in millimeters.

Zelotes occultus Tuneva et Esyunin, 2003

Figs 1-6, Map 1.

Zelotes occultus Tuneva et Esyunin, 2003: 225, f. 17-19 $\left(\mathrm{O}^{7}\right)$. MATERIAL EXAMINED. RUSSIA. Rostov Area: $10^{7}$ (CP), Sholokhovskiy Distr., near Elanskaya Vill., Don River plain $\left(49^{\circ}\right.$ $35^{\prime} \mathrm{N}, 42^{\circ} 4^{\prime} \mathrm{E}$ ), 1-7.IX.2004 (E.A. Khachikov); Volgograd Area: $11 \mathrm{O}^{\top} \mathrm{O}^{\top}, 5$ 우 (CP), Volgograd City, Grigorova Balka $\left(48^{\circ} 38^{\prime} \mathrm{N}\right.$, $44^{\circ} 23^{\prime} \mathrm{E}$ ), ravine forest, 1.V.-18.VI.2012 (A.S. Khnykin); 2 우 (PSU), Ilovlinskiy Distr., Trekhostrovskaya Vill., Natural Park "Donskoy" $\left(49^{\circ} 6^{\prime} \mathrm{N}, 43^{\circ} 51^{\prime} \mathrm{E}\right)$, edge of ravine forest, 4-26.VI.2013 (A.S. Khnykin). 


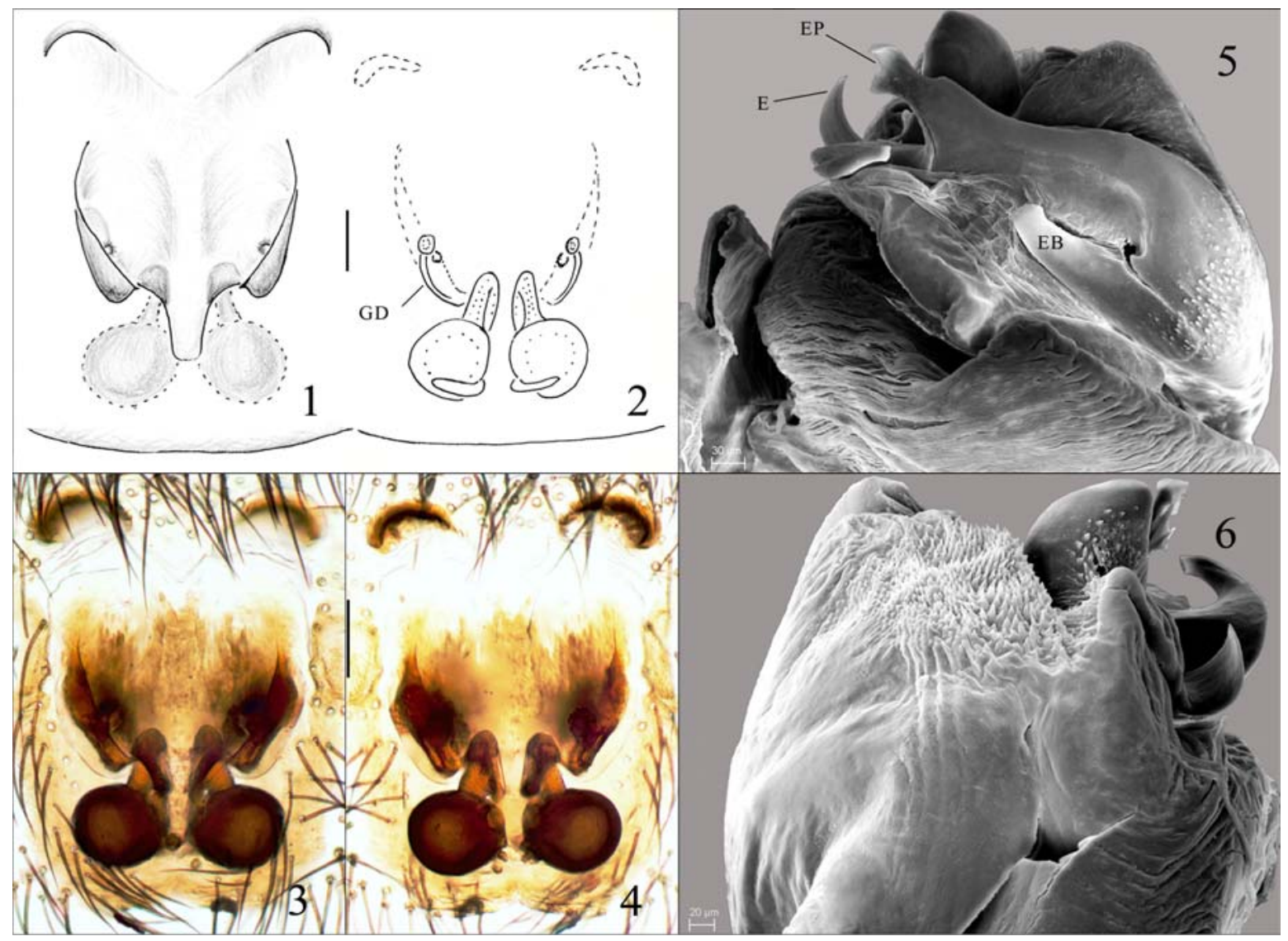

Figs 1-6. Male palp and epigyne of Zelotes occultus: 1,3 - epigyne, ventral; 2, 4 - epigyne, dorsal; 5 - tip of male palp, dorsal; 6 same, retrolateral. Scale bar $=0.1 \mathrm{~mm}$. Abbreviations: E - embolus; EB — embolar base; EP — embolar projection; GD - glandular ducts.

Рис. 1-6. Пальпа самца и эпигина Zelotes occultus: 1, 3 - эпигина, снизу; 2, 4 - эпигина, сверху; 5 - вершина пальпы самца, дорзально; 6 - то же самое, ретролатерально. Масштаб: 0,1 мм. Сокращения: Е - эмболюс; ЕВ - основание эмболюса; ЕР эмболюсный отросток; GD - проток железы.

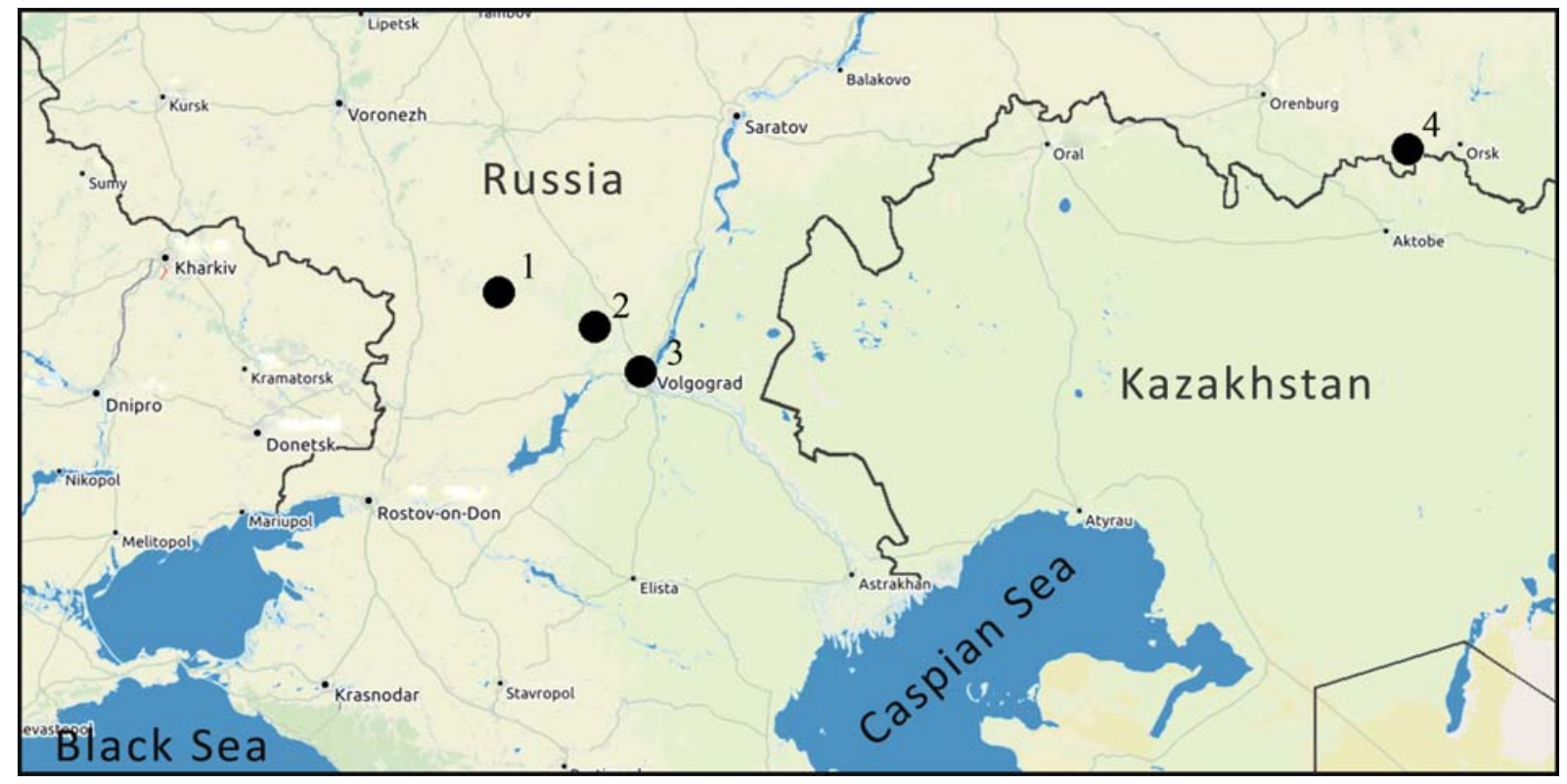

Map 1. Distribution of Zelotes occultus. 1 - Elanskaya Village; 2 - Trekhostrovskaya Village; 3 - Volgograd City; 4 - Orenburg Area, Kuvandyk District, Aituar.

Карта 1. Распространение Zelotes occultus. 1 - станица Еланская; 2 - станица Трехостровская; 3 - г. Волгоград; 4 Оренбургская обл., Айтуар. 
DIAGNOSIS. Zelotes occultus resembles Z. aeneus (Simon, 1878) and Z. egregius Simon, 1914 known from Europe but can be distinguished by the shorter embolus, wide and bifurcated tip of the embolar projection, and by the longer extension on the prolateral side of the embolar base (Figs 5-6). The female of $Z$. occultus can be separated from sibling species by the epigynal fovea with nearly extended lateral edges (vs. rounded in Z. aeneus and Z. egregius) and thin, elongated glandular ducts directed anteriorly ( $v s$. directed laterally in $Z$. aeneus and Z. egregious) (Figs 1-2).

DESCRIPTION

Male. Described in Tuneva \& Esyunin [2003].

Female. Total length 7.2 (6.55-7.85), carapace 2.9 (2.753.05) long, 2.28 (2.25-2.3) wide. Abdomen 4.3 (3.8-4.8) long, 2.63 (2.3-2.95) wide. Prosoma and legs brown. Leg spination: femur: I d1-1-0, p0-0-1; II d1-1-0, p0-0-1; III d11-0, p0-1-1, r0-1-1; IV d1-1-0, p0-1-1, r0-1-1; tibia: III, IV p1-1-1, r1-1-1, v2-2-2; metatarsus: I, II v2-0-0; III-IV p1-22, r1-2-2, v2-2-1. Abdomen gray. Epigynal plate longer than wide (Fig. 1). Anterior pockets long and widely separated. Lateral margins of epigynal fovea long, almost parallel. Glandular ducts directed longitudinally (Fig. 2).

Length of leg segments:

$\begin{array}{lcccccc} & \text { Fe } & \text { Pt } & \text { Ti } & \text { Mt } & \text { Ta } & \text { Total } \\ \text { I } & 2.25 & 1.35 & 1.5 & 1.4 & 1.2 & 7.7 \\ \text { II } & 1.95 & 1.15 & 1.35 & 1.35 & 1.35 & 7.15 \\ \text { III } & 1.85 & 0.85 & 1.25 & 1.55 & 1.0 & 6.5 \\ \text { IV } & 2.6 & 1.4 & 2.0 & 2.5 & 1.2 & 9.7\end{array}$

(Map 1).

DISTRIBUTION. Steppe zone of South-Eastern Europe

HABITATS. This species was collected in ravine forests on the plains of the Don and Volga Rivers. On the plains of the Ural River, it was found only in "bank of a brook in steppe" [Tuneva, Esyunin, 2003: 225].
Acknowledgments. We thank E.A. Khachikov (Rostovon-Don) and A.S. Khnykin (Volgograd) for providing us specimens for study. This study was supported by the State Contract of the Institute of Plant and Animal Ecology, UB RAS (project AAAA-A19-119031890085-3) and by the Southern Scientific Centre of RAS (project AAAA-A19119011190176-7). We are very grateful to V.Yu. Shmatko (SSC RAS, Rostov-on-Don) for taking the photographs. Special thanks go to Yuri Marusik for commenting on the manuscript.

\section{References}

Miller F. 1967. Studien über die Kopulationsorgane der Spinnengattung Zelotes, Micaria, Robertus und Dipoena nebst Beschreibung einiger neuen oder unvollkommen bekannten Spinnenarten // Acta scientiarum Academiae scientiarum bohemoslovacae. T.7. No.1. P.251-298.

Ponomarev A.V., Khnykin A.S. 2013. [Spiders (Aranei) of Volgograd city and its environs] // Yugh Rossii: ekologiya, razvitie. No.4. P.109-136 [in Russian, with English summary].

Senglet A. 2004. Copulatory mechanisms in Zelotes, Drassyllus and Trachyzelotes (Araneae, Gnaphosidae), with additional faunistic and taxonomic data on species from southwest Europe // Mitteilungen der Schweizerischen Entomologischen Gesellschaft. Vol.77. P.87-119.

Tuneva T.K., Esyunin S.L. 2003. A review of the Gnaphosidae fauna of the Urals (Aranei), 3. New species and new records, chiefly from the South Urals // Arthropoda Selecta. Vol.11 (2002). No.3. P.223-234.

Responsible editor Yu.M. Marusik 